\title{
The Purpose of Purification in Leviticus 16: A Proposition Pertaining to Priestly Prepositions
}

\author{
Joel S. Baden \\ Yale Divinity School, Yale University, New Haven, CT, USA \\ joel.baden@yale.edu
}

\begin{abstract}
The general function of the ritual described in Leviticus 16 is well known: it removes the impurities and the sins - unintentional and intentional - of the Israelites. A number of factors, however, contribute to obscure both some of the details about how the ritual operates and how it is conceived within the broader priestly ideology. This paper will attempt to clarify some issues relating to this text, with particular attention to the use of prepositions therein.
\end{abstract}

\section{Keywords}

Leviticus - Yom Kippur - priestly writings - priestly theology - prepositions

The general function of the ritual described in Leviticus 16 is well known: it removes the impurities and the sins - unintentional and intentional - of the Israelites. A trio of factors, however, contribute to obscure both some of the details about how the ritual operates and how it is conceived within the broader priestly ideology. These factors are the common translations of the verb כפר; the literary history of Leviticus 16 itself, which contains two ideologically distinct layers; and the complexities of the priestly literature as a whole, in which minor grammatical shifts are often indicative of much more. The following short study will attempt to clarify what the aforementioned factors have obבעד : scured, through the particular lens of two prepositions in the priestly text and על. 
The central verb (and concept) of Leviticus 16, appearing sixteen times in the chapter, is כפר, from which the name of the postbiblical Jewish holiday Yom Kippur derives. Yom Kippur is most often translated as "Day of Atonement," following on the standard English translation of כפר as "make atonement," going back to the Geneva Bible and the King James and continuing down to the present in the NRSV (with the NJPS providing the functionally identical "make expiation"). Yet as scholars increasingly recognize, this rendering of the verb כפר is misleading. In its original priestly context, the verb כפר is used to mean "purge": the removal, the wiping away, of sins and impurities. ${ }^{1}$

For the ritual of Leviticus 16, this purging is the end goal, accomplished through the sacrifice of purification (חטאת) and burnt (עלה) offerings. ${ }^{2}$ While the rendering "make atonement" puts the focus on the individual who is atoning, in fact the primary object being purged is not the individual, not the offeror of the sacrifices or prayers, but the sanctuary. This is clear from the details of the ritual - particularly the application of blood, the priestly "ritual detergent," to the physical space of the sanctuary ${ }^{3}$ - and also from the details of language used in the text. In the instructions for the sacrificial procedures, 16:2-28, the verb כפר is modified in two ways. When attached to the offerors Aaron, Aaron's household, or the Israelite community - the preposition used is invariably בעד, "on behalf of" (16:6, 11, 17, 24). The object being purged, by contrast - the Holy of Holies, the Tabernacle, the sacrificial altar - is marked by the preposition על (16:20). את (16:16, 18) or the particle

1 See Jacob Milgrom, Leviticus 1-16 (AB 3; New York: Doubleday, 1991), 1079-84. The understanding of the priestly ritual system assumed and argued in this paper is that of Milgrom. Acknowledging that challenges to parts of that system have been offered by other scholars, such as Roy Gane or Christophe Nihan, in this author's view it remains the most cogent explanation of the priestly ritual texts.

2 On the understanding of חטאת as "purification," see Jacob Milgrom, "Sin-Offering or Purification-Offering?," VT 21 (1971): 237-39.

3 The felicitous phrase "ritual detergent" is Milgroms's: Leviticus 1-16, 254.

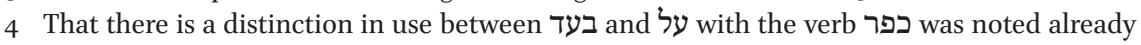
by Milgrom (Leviticus 1-16, 255-56), though his argument, that "ער can only refer to persons other than the subject, but when the subject wishes to refer to himself he must use בעד (10)," does not seem to account for the high priest's חעד העם (16:17, 24).

The one apparent exception to this neat prepositional division is found in 16:10, with reference to the scapegoat: this goat is not to be slaughtered, but left alive, לכפר עליו, to send it to Azazel in the wilderness. This use of על כל is so anomalous that it drove Milgrom to allow that here, almost uniquely, כפר "takes on the more abstract notion 'to expiate" (Leviticus 1-16, 1023). Milgrom also notes the rather desperate attempts of other scholars to make sense of the phrase: taking עליו as "in proximity to" (Baruch Levine, In the Presence of the Lord [Leiden: Brill, 1974], 80), or as referring to Aaron (Nobuyoshi Kiuchi, The Purification Offering in the Priestly Literature [јsотs 56; Sheffield: јsот Press, 1987], 209). The simplest solution would 
We can thus construct a complete ritual sentence, as it were: the חטאת sacrifices, with their accompanying עלה sacrifices, serve to purge (כפר) the physical spaces and objects of the sanctuary (עלה בעד הקדש) on behalf of Aaron and his household (בעדו ובעד ביתו) and on behalf of the people (ובעד העם). It is this purging of the sanctuary that is the ultimate goal of the entire ritual procedure, as 16:16 makes clear: "Thus he shall purge the holy space of the impurities of the Israelites, and of their transgressions, for all their sins, and thus he shall do for the Tent of Meeting." ${ }^{5}$ Within the overall project of $\mathrm{P}$, this makes perfect sense: All of the laws of Leviticus 1-15 are about the care and keeping of the Tabernacle: how to clean it when it has been contaminated with sins, and what sorts of human behaviors create impurities that must be kept away from the holy spaces.

While the ritual proper in $16: 2-28$ is focused exclusively on the sanctuary, the material found in 16:29-34 turns its attention to the Israelites. These verses are marked off as distinct from the rest of the chapter in multiple ways: the sudden use of the second-person plural; the specification of an annual day for the ritual, rather than the ad hoc timing presupposed in 16:2; the references to the ג, "stranger"; the mention of the generic high priest, rather than Aaron as previously in the chapter; and a number of terminological and stylistic features that, it has been suggested, are indicative of the Holiness layer of the priestly writings. ${ }^{6}$

For our purposes, however, the most salient feature of 16:29-34 is the marked shift in the function of the ritual, again indicated by the text's use of prepositions. In 16:30 we read that on this day יכפר עליכם - you, the Israelites, will be

seem to be that the phrase לכפר עליו here is a later addition. Not only is the prepositional use anomalous, but more decisively the conceptual use of כפר לפר here is difficult to explain. One cannot כפר without blood, the ritual purgative, yet no blood is applied to the scapegoat (nor is any of the scapegoat's blood shed). Moreover, the scapegoat exists precisely because the brazen sins of the Israelites cannot be purged; they can only be carried off into the wilderness. (Though not determinative, the parallel syntactic structure of this phrase with the one that follows, לשלח אתו, could indicate an addition meant to be read appositionally and means that לכפר עליו can be removed from the verse without any syntactic damage.) One might suggest that the phrase was added in light of the transformation of כפר לפר from the technical sense of purging to the broader sense of atonement: how could the scapegoat, the most unusual part of the ritual, not accomplish the main purpose of the ritual, of the Day of Atonement?

5 What may appear to be redundance in this verse is in fact progressive. As Liane Feldman explains, first Aaron must move the contamination from the inner space of the sanctuary into the outer courtyard of the Tent of Meeting, whence it can be permanently removed. Feldman, Story of Sacrifice, chapter 4, forthcoming.

6 See the detailed analysis of Christophe Nihan, From Priestly Torah to Pentateuch (FAT II/25; Tübingen: Mohr Siebeck, 2007), 346-50, and the references therein. 
purged. The preposition על that was used exclusively for the sanctuary, to mark the object of purgation, is now applied to the Israelites, for whom the purgation was previously only בעד, on their behalf. This is made even clearer by what follows in 16:30: לטהר אתכם מכל חטאתיכם , "to cleanse you from all your sins." Again, in the main body of the ritual, what is cleansed, טהם מכר לטת , is not the Israelites, but the altar: "he will cleanse (טהר) it of the impurities of the Israelites" (16:19). ${ }^{7}$

As is almost always the case with the later layers of the priestly materials, the new additions do not outright contradict the original text, but rather supplement it. The sanctuary is still being purged in the newly expanded text; but now the Israelites are as well. This is one of the primary emphases of the additional material, as is evident from the final verse, 16:34: "This shall be to you a law for all time, to purge (כפר) the Israelites from all of their sins once a year." It is this new purging of the Israelites themselves that accounts also for the requirement that they fast and abstain from working (16:29). Whereas in the original ritual the purging of the sanctuary was done on their behalf, now it is being done to them - and since the blood, the ritual detergent, cannot be applied directly to each Israelite as it is to the sanctuary, their fasting and abstaining from work serves to implicate them in the cleansing process, to make them present even from a distance. ${ }^{9}$

The author of this secondary expansion was, it would seem, a keen reader of the preexisting priestly text. The preposition בעד, "on behalf of," is nowhere to be found here, as that category has been eliminated: everyone is a direct participant. And על, which marked the object of כפר, is applied in these verses exclusively to the people $(16: 30,33,34)$, as if to make clear the equivalence between the purging of the sanctuary, על הקדש, and that of the people, על בני ישראל It is little wonder, then, that later readers were not always able to recognize the distinctiveness of the earlier ritual.

7 Furthermore, as Feldman notes (Story, chapter 4), Lev 16:30 has the Israelites being cleansed, טהר, of their sins, חטאתיכם, which is, following the original priestly concept, a category error: one is cleansed of impurities, not sins. See further below.

8 The same purpose for the ritual is articulated in the festival calendar of Leviticus 23, which almost certainly belongs to the same compositional layer as the additional material at the

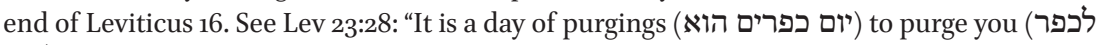
עליכם (על She status of Leviticus 23, see especially Christophe Nihan, "Israel's Festival Calendars in Leviticus 23, Numbers 28-29, and the Formation of 'Priestly' Literature," in The Books of Leviticus and Numbers (ed. Thomas Römer; BETL 215; Leuven: Peeters, 2008), 177-231.

9 In the basic priestly sacrificial system, when individuals offer חטאת sacrifices, they need not fast nor abstain from work; this is true even when it is the entire community that has sinned. The priest does all of the ritual work, on behalf of the offeror. The introduction of any sort of enforced behavior on the lay Israelite here in Leviticus 16 means that they are being involved in the ritual in a novel way. 
Adding further to the difficulty in understanding the function of the prepositions in Leviticus 16 is the fact that $\mathrm{P}$ itself is inconsistent in its prepositional use from section to section. Everywhere in the sacrificial regulations of כפר Leviticus 1-7, and also in the impurity laws of Leviticus 11-15, the phrase על takes as its object the offeror, rather than the altar or Tabernacle. Yet it is clear that it is not the offeror that is being purged, but in fact the offeror's sin or impurity.

וכפר עליו הכהן על חטאתו אשרחטא , כפר על him (the offeror), על his sin which he has sinned," or variations thereon. ${ }^{10}$ The second על על phrase, that refers explicitly to the sin, makes clear what is meant: the sin is what is purged. And in every single case in Leviticus 4 and 5 where כפר על is used this way, it is always followed by ונסלח - the end result of the ritual is that the sinner is forgiven, not purged.

A parallel situation obtains in Leviticus 11-15. In those chapters, as exemplified by the parturient in Lev 12:7, the person with a major impurity brings a כטאת offering, the priest עפר עליה, "purges על her," and as a result וטהרה, "she will be pure." Here it is not that impurity is being removed from the person via the כפר mechanism; impurity is removed from an individual by bathing and waiting until sunset, as we know from the cases of the minor impurities, and from the fact that even with the major impurities the impure person must still bathe and become clean before offering the חטאת, since one cannot enter the sanctuary in a state of impurity.11 The חטאת sacrifice, here as everywhere, removes, כפר, the contamination from the sanctuary; this is why the blood of the חטאת is applied to the altar, and not to the offeror: as ritual detergent, it is placed on the thing that requires purging.

Thus with regard to both sins, in Leviticus 4-5, and impurities, in Leviticus 11-15, there is a clear and regular distinction. The sanctuary requires purgation, כפר ; the individual requires forgiveness (סלח), in the case of sins, or cleaning (טהר), in the case of impurities. ${ }^{12}$ Forgiveness for sins comes with the offering of the חטאת sacrifice, that is, with the purging, כפר, of the contaminated sancta. Cleaning from impurity comes not from the offering of the מטאת, but with bathing and the passage of time.

10 For the exact phrase, see also Lev 5:13; with שגנגו rather than מטאתו 5:18; with rather than על חטאתו 4:26; 5:6, 10.

11 The classic expression of the sequence of bathing and waiting before entering the sanctuary is Lev 15:13-15, regarding the man who has had a genital discharge: once his discharge ends, he waits seven days, washes his clothes and bathes his body, at which point he is clean, וטהר. The next day he takes two birds, one as a עלה and one as an עטאת, to the sanctuary, where they are sacrificed; thus the priest purges on his behalf, וכפר עליו הכהן. 
In other words, in Leviticus 1-4, כפר על 11-11 כפר בעד is used just as is used in Leviticus 16. Thus a canonical reader - or even one simply reading P in its current order - encounters the phrase כפר על first, and repeatedly, in Leviticus $1-4,11-15$ with the meaning "purges on behalf of"; when it suddenly means something different in Leviticus 16 there is good reason for some confusion.

Yet it may be noted that there is a specific set of other P texts in which the כפר בעד and כפר על and used just as we find them in Leviticus 16. In Exodus 29, where Moses is receiving instructions on how to ordain Aaron and his sons for the priesthood, he is commanded to offer a bull as a חטאת every day for seven days, the sacrifice of which upon the altar will purge it, בכפרך עליו 29:36). The following verse, 29:37, is even clearer: "Seven days you will purge the altar," שבעת ימים תכפר על-המזבח. So too in the chapter in which the ordination of Aaron and his sons actually takes place, Leviticus 8: Moses applies the blood to the altar לכפר עליו, "to purge it" (8:15). Tellingly, later in that chapter the phrase כפר על is used with reference to Aaron and his sons, עליכם (8:34) - and here, uniquely, they are in fact to be understood as the objects of the verb: here on the final day of their ordination process they are being purged, because they are about to become sancta themselves..$^{13}$ Thus this apכפר parent exception is in fact even firmer evidence for the consistent use of על in the priestly ordination chapters.

To close the circle, the phrase כפר בעד, "purge on behalf of," is found in P only in Leviticus 16 and in Leviticus 9, the inauguration of the Tabernacle and its sacrificial service that concludes Aaron's ordination (or, perhaps better, for which Aaron's ordination is a prerequisite). There Aaron offers a חטאת for himself and one for the Israelite people, along with their accompanying עלה offerings - just as he is instructed to do in Leviticus 16. In Lev 9:7 we read: "Offer עטאת your and your עפר בעדך and and offer the sacrifice of the people and כפר בעדם." Not only is the sacrificial procedure in Leviticus 9 remarkably close to that of Leviticus 16, but even the language, down to the use of the preposition בעד, is identical. ${ }^{14}$ Leviticus 9 and 16 are, in fact, the only places in the entirety of $\mathrm{P}$ where the word בעד appears at all.

We can thus observe two distinct blocks of priestly text: Leviticus 1-4, 11-15 on one hand, and Exodus 29, Leviticus 8-9, and Leviticus 16 on the other,

13 On the understanding of priests as sancta like the sanctuary and its appurtenances, see Menahem Haran, Temples and Temple Service in Ancient Israel (Winona Lake: Eisenbrauns, 1985), 177: "The anointing endows the priests and their vestments with the same holiness as that of the Tabernacle."

14 On the closely parallel sacrificial procedures of Leviticus 9 and 16, see Liane Feldman, "Ritual Sequence and Narrative Constraints in Leviticus 9:1-10:3," JHS 17 (2017): 1-35 (at 13-27). 
distinguishable by, among other things, their uses of the prepositional phrases For some scholars, this observation may be evidence for multiple layers of composition within the priestly writings, or as support for the theory that the priestly corpus is a collection and edition of previous independent scrolls and texts and torahs. ${ }^{15}$

Yet there is good internal logic to the alignment of Leviticus 16 with the ordination of Aaron and the inauguration of the Tabernacle, without the need for composition-historical theories. The use of בעד in Leviticus g is not simply a stylistic variant. In cases like Lev 4:35, and virtually everywhere else in P, a reader familiar with the priestly ritual concepts would not be confused by the phrase וכפר עליו, as it is only sancta that require, or can receive, purgation. As the individual Israelite in question is not sacred, כפר עליו can only mean "purge on his behalf"; "purge him" would be meaningless. But after the ordination of the priests, there are people who are also sancta, and so the phrase כפר עליו would be ambiguous: purge on behalf of the priest, as with a regular Israelite, or purge the priest, as with the sanctuary? The preposition בעד, employed first in this context, is clarifying: on behalf of the priest. (This is sensible enough since, as noted above, the priests have already been the object of כפר, just a few verses earlier in Lev 8:34.)

Leviticus 16 presents another situation where the high priest, who is himself sancta, is offering a חטאת that could in theory serve either to כפר on his behalf or to כפר him directly. Thus the same prepositional distinction is necessary, to clarify that it is in fact the sanctuary that is being purged, not the priest. ${ }^{16}$ Beyond that, however, the parallel prepositional uses signal a deeper ritual parallel between the ordination/inauguration of Leviticus 8-9 and the purgation of Leviticus 16.

The result of the sacrificial procedures in Leviticus 16 is not merely the removal of sins and impurities from the sanctuary. It is a return to the very beginning of the sanctuary's existence, to the Tabernacle's state at the moment of its inauguration. This is signaled by the specific use of prepositions, supported by the almost identical sacrifices, and all but confirmed by the notice in 16:19 that Aaron will קדש, sanctify, the altar. The only other place where the altar is

\footnotetext{
15 See, e.g., Milgrom, Leviticus 1-16, 63: "the redactor of $\mathrm{P}$ is responsible for ... the present arrangement of Lev 1-16, that is, the insertion of the large blocs, the sacrificial laws (chaps. 1-7) and the impurity laws (chaps. 11-15) - which may have existed as independent and discrete scrolls - in their present places."

16 The other priestly ritual text in which the high priest brings a חטאת sacrifice on his own behalf is Lev 4:3-12. While we would expect that this passage would also require the distinction between כפר בעד and כפר על in fact the verb כפר is never used at all here (though it is used in every other case presented in the chapter: 4:20, 26, 31, 35).
} 
sanctified is, naturally enough, at its inauguration, instructed to Moses in Exod 29:37 and 40:10, and fulfilled in Lev 8:11 and 15. There Moses takes the anointing oil and sprinkles it on the altar seven times - just as Aaron does with the blood in Lev 16:19 - and applies the blood of the חטאת offering to the altar to sanctify it, just as Aaron does.

Though obscured by the inherent complexity of priestly style, by our modern distance from the genre of the ritual text, and by the secondary expansion at the end of the chapter, the original function of the ritual in Leviticus 16 is still discernible, and with a close focus on the language used there, and its unique parallels with the ordination and inauguration passages, can be brought into even sharper focus. The ritual of Leviticus 16 is a reset button for the sanctuary, restoring the Tabernacle to its original factory settings.

\section{Acknowledgements}

The basic outlines of this argument were originally presented at a conference at Yale and at a workshop at the University of Chicago, both in the fall of 2013. Deepest thanks to Liane Feldman for encouraging me to finally publish it, and for her comments on earlier drafts of the paper. 